\title{
SOEP
}

SOEPpapers

SOEPpapers
on Multidisciplinary Panel Data Research

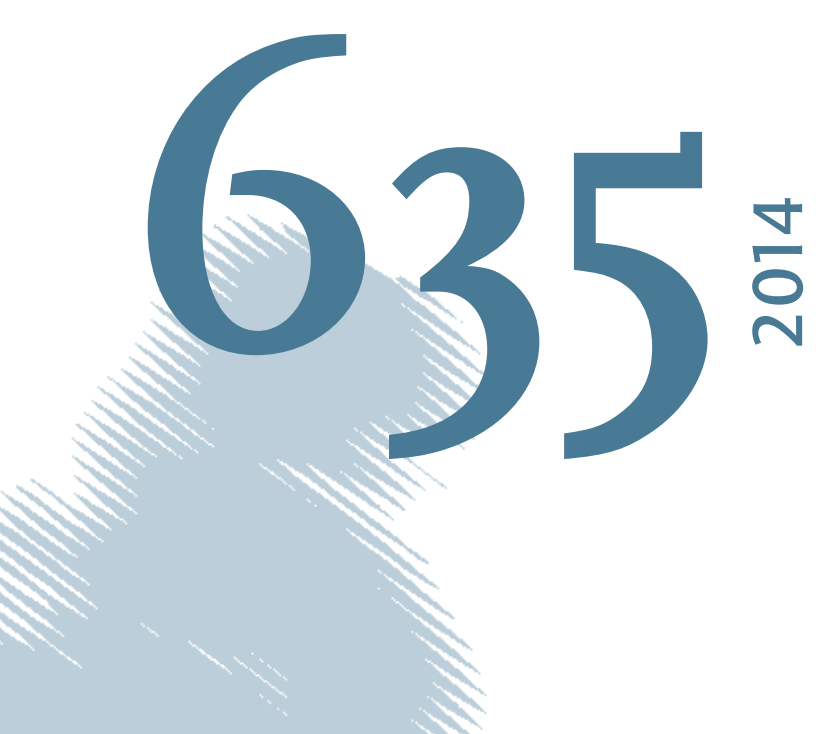

\section{A weighty issue revisited: the dynamic effect of body weight on earnings and satisfaction in Germany}




\section{SOEPpapers on Multidisciplinary Panel Data Research}

at DIW Berlin

This series presents research findings based either directly on data from the German SocioEconomic Panel Study (SOEP) or using SOEP data as part of an internationally comparable data set (e.g. CNEF, ECHP, LIS, LWS, CHER/PACO). SOEP is a truly multidisciplinary household panel study covering a wide range of social and behavioral sciences: economics, sociology, psychology, survey methodology, econometrics and applied statistics, educational science, political science, public health, behavioral genetics, demography, geography, and sport science.

The decision to publish a submission in SOEPpapers is made by a board of editors chosen by the DIW Berlin to represent the wide range of disciplines covered by SOEP. There is no external referee process and papers are either accepted or rejected without revision. Papers appear in this series as works in progress and may also appear elsewhere. They often represent preliminary studies and are circulated to encourage discussion. Citation of such a paper should account for its provisional character. A revised version may be requested from the author directly.

Any opinions expressed in this series are those of the author(s) and not those of DIW Berlin. Research disseminated by DIW Berlin may include views on public policy issues, but the institute itself takes no institutional policy positions.

The SOEPpapers are available at

http://www.diw.de/soeppapers

\section{Editors:}

Jürgen Schupp (Sociology)

Gert G. Wagner (Social Sciences, Vice Dean DIW Graduate Center)

Conchita D'Ambrosio (Public Economics)

Denis Gerstorf (Psychology, DIW Research Director)

Elke Holst (Gender Studies, DIW Research Director)

Frauke Kreuter (Survey Methodology, DIW Research Professor)

Martin Kroh (Political Science and Survey Methodology)

Frieder R. Lang (Psychology, DIW Research Professor)

Henning Lohmann (Sociology, DIW Research Professor)

Jörg-Peter Schräpler (Survey Methodology, DIW Research Professor)

Thomas Siedler (Empirical Economics)

C. Katharina Spieß (Empirical Economics and Educational Science)

ISSN: 1864-6689 (online)

German Socio-Economic Panel Study (SOEP)

DIW Berlin

Mohrenstrasse 58

10117 Berlin, Germany

Contact: Uta Rahmann | soeppapers@diw.de 


\title{
A weighty issue revisited: the dynamic effect of body weight on earnings and satisfaction in Germany
}

\author{
Frieder Kropfhäußer \\ Marco Sunder* \\ IWH Halle \\ Leipzig University \\ frieder.kropfhaeusser@iwh-halle.de \\ sunder@wifa.uni-leipzig.de
}

February 14, 2014

\begin{abstract}
We estimate the relationship between changes in the body mass index $(b m i)$ and wages or satisfaction, respectively, in a panel of German employees. In contrast to previous literature, the dynamic models indicate that there is an inverse $\mathrm{u}$-shaped association between $b m i$ and wages among young workers. Among young male workers, work satisfaction is affected beyond the effect on earnings. Our finding of an implied optimum bmi in the overweight range could indicate that the recent rise in weight does not yet constitute a major limitation to productivity.
\end{abstract}

Keywords: Obesity, earnings, System-GMM estimator, dynamic panel model, SOEP

JEL classification: J24, J28, J31, J71

${ }^{*}$ Corresponding author. Address: Institute for Empirical Research in Economics, Leipzig University. Grimmaische Str. 9, 04109 Leipzig, Germany. Phone: +49 3419733786. 


\section{Introduction}

The global rise in obesity has stirred a large body of research, not only on the physiological consequences of obesity but also on its psychological burden and its effects in the labour market (Cawley, 2004, Puhl and Heuer, 2009). In the US, obese persons are more likely than those with normal weight to report day-to-day interpersonal discrimination. Carr and Friedman (2005) find that this difference is larger in higher socio-economic strata, and that perceived discrimination is an important factor in explaining lower self-acceptance among the obese. It is not so clear, though, whether the psychological burden works on top of the effect on labour market outcomes. The relationship may also be country-specific, due to cultural differences and different legal frameworks (Brunello and D'Hombres, 2007).

We analyse the association of body mass index (bmi) with wages and satisfaction among German workers picking up the idea of country-specific differentials in the $b m i$-wage relationship. While $b m i$ has clear limitations as a measure of central body fat (as muscle mass contributes even more to weight than fat mass), this information is now included in several surveys with detailed information on income.

In contrast to findings from the US Averett and Korenman, 1996, Cawley, 2004 Baum and Ford, 2004), previous studies on the causal relationship from bmi to wages have not found a weight penalty in the case of Germany (Cawley et al. 2005, Bozoyan and Wolbring, 2011). Apart from differences in model specification, such a result may reflect a higher degree of regulation in the German labour market. Compared to the US, the German labour market is often assumed to be rigid and inflexible (Nickell, 1997; Franz and Pfeiffer, 2006). While previous studies on the effect of $b m i$ on wages have used cross-sectional models or static panel data models, our dynamic panel model takes into account the possibility of earnings persistence, thus allowing the full adjustment of wages to take some time. Using panel data also allows us to filter out time-invariant heterogeneity across workers.

In the context of the effect of schooling on wages, Andini (2013a) has recently argued that static models might underestimate the full effect of schooling. Fur- 
thermore, Andini (2013b) provides a theoretical derivation of the dynamic form of a Mincer regression equation as the outcome of a wage bargaining model. In this context, bmi might be more important for younger workers since employers could regard weight gain as a signal for low productivity in the future (Pinkston, 2010). To be sure, this reasoning may not hold for very low levels of $b m i$, so non-linearity in the relationship should be accounted for by the regression model. However, most studies on the causal effect of bmi have assumed a linear relationship (Cawley, 2004. Baum and Ford, 2004, Brunello and D'Hombres, 2007; Bozoyan and Wolbring, 2011, Cawley et al., 2005).

In case there really was a burden from weight on worker productivity and this burden was not absorbed by wages, one could speculate that other forms of discrimination - such as bullying — still play a role, possibly an even larger one. This could then show up in the form of greater disutility of labour (at given earnings) among workers who just became more chubby. This channel might explain the observation that happiness is a negative function of weight and that the strength of this relationship varies across countries (Katsaiti, 2012). We address this channel by using indicators of satisfaction with life and satisfaction with work as additional outcome measures, again within a dynamic panel framework.

\section{Material and method}

Our analysis is based on data from the German Socio-Economic Panel study (SOEP v28, 2012, Wagner et al., 2007). Anthropometric information in this panel is selfreported and only available at biennial frequency, which is why we use two-year intervals in our analysis. While variables other than $b m i$ are taken from odd years $(2003,2005,2007,2009,2011)$, the information on $b m i$ refers to the respective preceding, even year. Several inclusion criteria were applied. We only consider employees aged 65 years or younger, who worked for at least 10 hours per week, and who earned a (nominal) hourly wage of at least 1 EUR. Observations with imputed anthropometric or wage data are excluded from the analysis, and we also disregard 
data on women who were - according to their fertility history - pregnant at the time of the anthropometric interview or who had given birth to a child shortly before.

The dependent variable in our wage regression is the natural logarithm of the deflated gross hourly wage. The models on satisfaction use either subjective wellbeing with life in general or with work as dependent variable. While these variables are measured on a Likert-type scale ranging from 0 (dissatisfied) to 10 (satisfied), we treat them as if they were metrical variables, similar to previous literature (e.g., Katsaiti, 2012). Our explanatory variable of interest is bmi, defined as weight in kilograms divided by height in meters squared. In order to reflect a non-linear relationship, we also use the square of this variable. If anything, we would expect to find an inverse $\mathrm{u}$-shape association, with an implied maximum in the healthy bmi range. ${ }^{1}$ The resulting effective sample is not balanced but requires that information from at least three consecutive waves is available for a particular individual. ${ }^{2}$

For each outcome variable, we specify a separate dynamic regression equation of the form

$$
y_{i t}=\alpha_{i}+\sum_{j=1}^{p} \gamma_{j} y_{i, t-j}+\beta_{1} b m i_{i t}+\beta_{2}\left(b m i_{i t}\right)^{2}+\boldsymbol{x}_{i t}^{\prime} \boldsymbol{\delta}+\varepsilon_{i t},
$$

where $\alpha_{i}$ is a person fixed effect, $\boldsymbol{x}_{i t}$ contains control variables (including exogenous dummies for time), and $\varepsilon_{i t}$ is an error term that needs to be uncorrelated over time. To be sure, substantial differences in initial $b m i$ across people are absorbed by the fixed effect, so that identification of $\beta_{1}$ and $\beta_{2}$ rests only on the intra-personal variation in $b m i$ over time. We believe that this cautionary approach is required to avoid omitted variable bias, because personality traits that we do not account for in the model - in particular self-control - may affect both a worker's bmi and the outcome variables.

In general, we believe that $b m i$ is not exogenous but might react to shocks in income or happiness, respectively. Notice that by construction of our dataset,

\footnotetext{
${ }^{1}$ It is often assumed that a healthy $b m i$ falls into the range $18.5-25$, whereas $25-30$ marks overweight, and values above 30 indicate obesity.

${ }^{2}$ This number increases to four if the specification includes two lags of the dependent variable.
} 
Table 1: Descriptive statistics for the regression subsamples

\begin{tabular}{|c|c|c|c|c|c|c|c|c|}
\hline & \multicolumn{4}{|c|}{ Male workers } & \multicolumn{4}{|c|}{ Female workers } \\
\hline & \multicolumn{2}{|l|}{ all } & \multicolumn{2}{|c|}{ young } & \multicolumn{2}{|l|}{ all } & \multicolumn{2}{|c|}{ young } \\
\hline & mean & s.d. & mean & s.d. & mean & s.d. & mean & s.d. \\
\hline $\ln ($ real hourly wage $)$ & 2.776 & 0.502 & 2.643 & 0.507 & 2.513 & 0.491 & 2.422 & 0.465 \\
\hline satisfaction with life & 7.121 & 1.537 & 7.291 & 1.455 & 7.052 & 1.619 & 7.188 & 1.560 \\
\hline satisfaction with work & 6.982 & 1.917 & 7.171 & 1.815 & 6.943 & 1.915 & 7.057 & 1.927 \\
\hline$b m i$ & 26.692 & 3.813 & 25.541 & 3.642 & 24.922 & 4.552 & 23.815 & 4.278 \\
\hline schooling & 12.943 & 2.858 & 13.345 & 2.890 & 12.859 & 2.684 & 13.199 & 2.779 \\
\hline experience & 22.710 & 10.059 & 9.645 & 3.820 & 21.154 & 9.559 & 9.429 & 3.840 \\
\hline East Germany & 0.215 & 0.411 & 0.215 & 0.411 & 0.265 & 0.442 & 0.208 & 0.406 \\
\hline $\ln ($ realearnings $)$ & 8.030 & 0.534 & 7.888 & 0.540 & 7.501 & 0.639 & 7.414 & 0.635 \\
\hline $\ln ($ hours $)$ & 3.785 & 0.195 & 3.777 & 0.198 & 3.519 & 0.357 & 3.523 & 0.371 \\
\hline age & 45.477 & 9.707 & 33.607 & 5.572 & 45.503 & 9.517 & 35.069 & 7.785 \\
\hline married & 0.710 & 0.454 & 0.484 & 0.500 & 0.646 & 0.478 & 0.488 & 0.500 \\
\hline Observations & 11,514 & & 2,906 & & 8,910 & & 2,506 & \\
\hline
\end{tabular}

$b m i_{i t}$ refers to the preceding year, and it should thus not be able to react to current shocks but only to past shocks. As a consequence, we treat bmi as a predetermined variable. This means that, within a GMM framework, the first lag $\left(b m i_{i, t-1}\right)$ can serve as an instrument for $\Delta b m i_{i t}$ in the difference equation (Cameron and Trivedi, 2005 p. 765). Estimation is carried out with the System-GMM estimator that additionally considers a levels equation (Blundell and Bond, 1998). Compared to a cross-sectional OLS specification, this model removes unmeasured time-invariant factors (unobserved heterogeneity), tackles potential endogeneity of $b m i$, and allows for a potentially sluggish adjustment of the outcome measure to its new equilibrium. In search of a parsimonious specification, we only consider $p \in\{1,2\}$, based on residual autocorrelation tests.

In the wage regression, we use years of schooling, years of actual labour market experience, and a dummy for East Germany as additional control variables, all of which are assumed to be exogenous. ${ }^{3}$ Our models on subjective well-being incorporate earnings and the number of work hours (both in natural logarithm) as explanatory variables presumed to be predetermined. All other regressors are be-

\footnotetext{
${ }^{3}$ Years of schooling is the hypothetical number of years required to receive the individual's highest degree, irrespective of actual time spent in formal education. As our sample contains only individuals with completed education, this variable is time-invariant and thus could not be used in the Arellano/Bond GMM estimator. In the System-GMM specification we consider schooling as an exogenous regressor for simplicity. See Kripfganz and Schwarz (2013) for a framework in which time-invariant regressors can be instrumented.
} 
lieved to be exogenous. All estimations are stratified by gender. In order to account for the effect that $b m i$ - as a potential signal for future productivity - might be of particular relevance for the wage of younger workers, we also consider sub-samples restricted to 'young' workers, defined as those with a labour market experience of 15 years or less. Descriptive statistics for all four sub-samples are depicted in Table 11.

A possible limitation of our approach is that we require workers with several waves of data, which could imply sample selection issues. E.g. we do not model the probability that a high $b m i$ could increase the risk of being jobless. In addition, we are unable to account for effects of $b m i$ that occur when-or before-people enter the workforce, in particular schooling outcomes (Chen, 2012). Hence, some of the effects of bmi might be obscured in our analysis as part of unobserved heterogeneity.

\section{Results}

Table 2 presents results for the augmented dynamic Mincer regression. All specifications pass the residual autocorrelation test and the Hansen test on instrument exogeneity. With a moderate number of (at most) 43 instruments, we believe that the Hansen tests are not biased. This also applies for models on subjective wellbeing with at most 70 instruments. ${ }^{4}$ Following Roodman (2009b) we additionally re-estimate our models for earnings and subjective well-being using the minimum amount of instruments and find no evidence for systematically inflated Hansen pvalues (see Tables 4 and 5 in the Appendix).

While the autoregressive wage coefficient is statistically significant, it turns out to be relatively small. Thus, the model implies only modest wage persistence or small differences between effects in the short run and the long run. In the male young worker model, both $b m i$ and its square turn out to be statistically significant. With a positive and negative sign, respectively, they imply an inverse u-shaped relationship. However, the 'optimum $b m i$ - the value of $b m i$ that maximizes earnings ceteris

\footnotetext{
${ }^{4}$ Roodman (2009a) e.g. proposes a rule of thumb according to which instruments should not outnumber individual units in the panel.
} 
Table 2: Wage regression results

\begin{tabular}{|c|c|c|c|c|}
\hline & \multicolumn{2}{|c|}{ Male workers } & \multicolumn{2}{|c|}{ Female workers } \\
\hline & $\begin{array}{l}\text { all } \\
(1)\end{array}$ & $\begin{array}{r}\text { young } \\
(2)\end{array}$ & $\begin{array}{l}\text { all } \\
(3)\end{array}$ & $\begin{array}{r}\text { young } \\
(4)\end{array}$ \\
\hline$y(t-1)$ & $\begin{array}{l}0.1983^{* * *} \\
(0.0389)\end{array}$ & $\begin{array}{l}0.2841^{* * *} \\
(0.0775)\end{array}$ & $\begin{array}{l}0.1520^{* * *} \\
(0.0401)\end{array}$ & $\begin{array}{l}0.2270^{* * *} \\
(0.0680)\end{array}$ \\
\hline$b m i$ & $\begin{array}{r}0.0297 \\
(0.0274)\end{array}$ & $\begin{array}{l}0.1472^{* *} \\
(0.0611)\end{array}$ & $\begin{array}{c}0.0531^{* *} \\
(0.0211)\end{array}$ & $\begin{array}{c}0.0953^{* *} \\
(0.0370)\end{array}$ \\
\hline$(b m i)^{2}$ & $\begin{array}{l}-0.0005 \\
(0.0005)\end{array}$ & $\begin{array}{l}-0.0024^{* *} \\
(0.0011)\end{array}$ & $\begin{array}{l}-0.0009^{* *} \\
(0.0004)\end{array}$ & $\begin{array}{l}-0.0018^{* * *} \\
(0.0006)\end{array}$ \\
\hline schooling & $\begin{array}{l}0.0676^{* * *} \\
(0.0036)\end{array}$ & $\begin{array}{l}0.0622^{* * *} \\
(0.0068)\end{array}$ & $\begin{array}{l}0.0754^{* * *} \\
(0.0041)\end{array}$ & $\begin{array}{l}0.0647^{* * *} \\
(0.0057)\end{array}$ \\
\hline East Germany & $\begin{array}{l}-0.3265^{* * *} \\
(0.0203)\end{array}$ & $\begin{array}{l}-0.2270^{* * *} \\
(0.0320)\end{array}$ & $\begin{array}{l}-0.2325^{* * *} \\
(0.0178)\end{array}$ & $\begin{array}{l}-0.2221 \text { *** } \\
(0.0281)\end{array}$ \\
\hline experience & $\begin{array}{l}0.0229^{* * *} \\
(0.0028)\end{array}$ & $\begin{array}{r}0.0056 \\
(0.0161)\end{array}$ & $\begin{array}{l}0.0214^{* * * *} \\
(0.0030)\end{array}$ & $\begin{array}{r}0.0172 \\
(0.0129)\end{array}$ \\
\hline$(\text { experience })^{2}$ & $\begin{array}{l}-0.0004^{* * *} \\
(0.0001)\end{array}$ & $\begin{array}{r}0.0004 \\
(0.0007)\end{array}$ & $\begin{array}{l}-0.0003^{* * *} \\
(0.0001)\end{array}$ & $\begin{array}{l}-0.0004 \\
(0.0006)\end{array}$ \\
\hline Observations & 11,514 & 2,906 & 8,910 & 2,506 \\
\hline Persons & 4,858 & 1,639 & 3,963 & 1,509 \\
\hline \multicolumn{5}{|c|}{ Arellano-Bond autocorrelation test (p-value) } \\
\hline first order & 0.0000 & 0.0004 & 0.0000 & 0.0000 \\
\hline second order & 0.9815 & 0.2946 & 0.7711 & 0.7486 \\
\hline \multicolumn{5}{|c|}{ Hansen test on instrument exogeneity (p-value) } \\
\hline Model & 0.6656 & 0.6696 & 0.7036 & 0.8354 \\
\hline$\Delta J$ for level eq. & 0.4109 & 0.7554 & 0.6026 & 0.4154 \\
\hline Instruments & 34 & 43 & 43 & 43 \\
\hline Implied bmi & 32.3 & 30.4 & 29.6 & 26.6 \\
\hline
\end{tabular}

Remarks: Method of estimation: System-GMM. Models additionally include an intercept term and year dummies. Robust standard errors with Windmeijer correction in parentheses. $* / * * / * * *$ indicates statistical significance at the $10 / 5 / 1 \%$ level. See text for definition of subsamples.

paribus - is only achieved at a bmi of 30 (Figure 1 a)), i.e. at the threshold from 'overweight' to 'obesity'.

For female workers (in general) the maximum is reached at about the same $b m i$ value, whereas the respective number is 'only' 27 (overweight) for young female workers (Figure 1 b)). The relationship also seems to be stronger among young workers. Our estimates suggest that for a young female worker with a bmi of 20 , an increase in $b m i$ by one unit would be associated with an increase in wage by c. $2.3 \%$ 'on impact' (i.e. one year later). In the very long run, the predicted wage increase (due to a permanent $b m i$ increase) amounts to c. $3.0 \% .^{5}$ If we restrict the coefficient on $b m i^{2}$ to be zero, the coefficient on $b m i$ becomes insignificant, which suggests that non-linearity should be taken into account (see Table 6 in the Appendix).

The results on subjective well-being differ between genders (Table 3). Life

$$
{ }^{5} 100 \times \frac{0.0953-2 \cdot 0.0018 \cdot 20}{1-0.2270}
$$


a) Young male workers

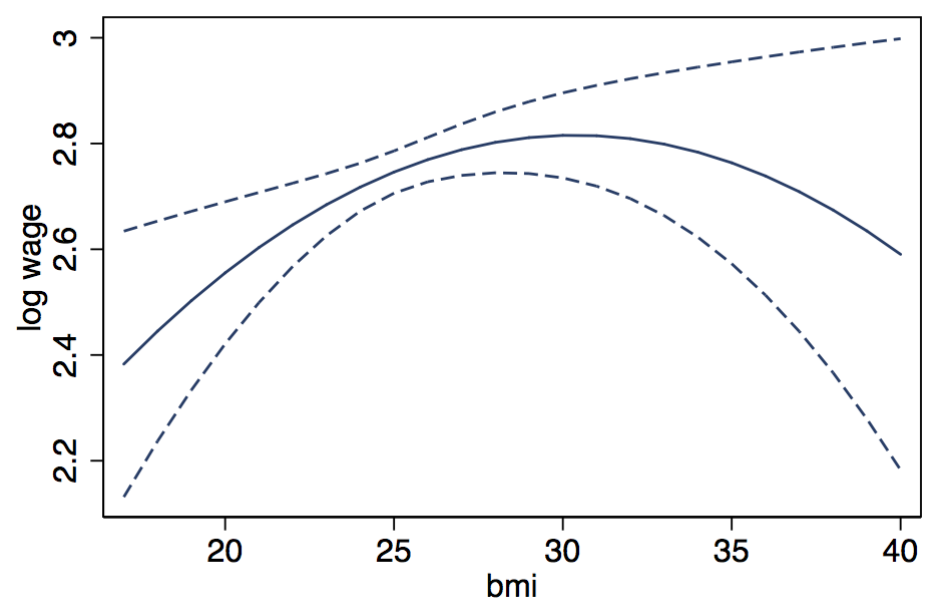

b) Young female workers

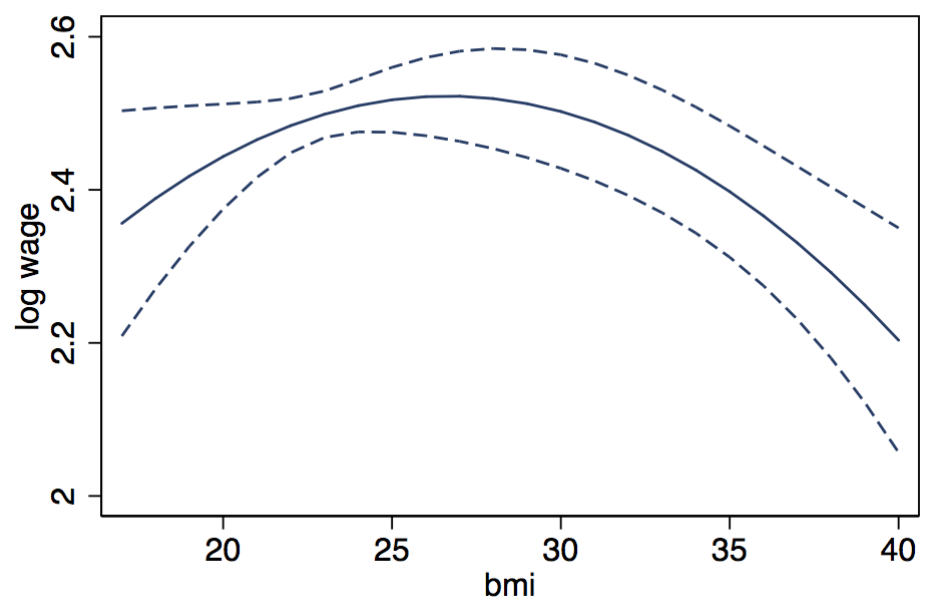

Figure 1: Estimated short-run relationship between $b m i$ and log hourly wage, with approximate $95 \%$ confidence interval. Calculated from Table 2 , cols. 2 and 4 .

satisfaction among male workers does not significantly react to changes in $b m i$, but for female workers the relationship is statistically significant. Once again, the optimum value is quite high, at a $b m i$ near 29 . Notice that these models already control for individual earnings. The $b m i$ relationship among women need not accrue from discrimination as it could also reflect health-related concerns or limitations. When work satisfaction is considered as outcome, we find the inverse u-shape again, but it is not statistically significant for women. For young male workers, however, it is statistically significant, with an implied optimum at a $b m i$ of 29 . That this effect works in addition to the effect on earnings hints at a subtle form of discrimination at the workplace. As was the case with the wage regression, the autoregressive 
Table 3: Regression results for satisfaction with life and work

\begin{tabular}{|c|c|c|c|c|c|c|}
\hline & \multicolumn{3}{|c|}{ Male workers } & \multicolumn{3}{|c|}{ Female workers } \\
\hline & $\begin{array}{r}\text { Life } \\
\text { all } \\
(1)\end{array}$ & $\begin{array}{r}\text { Work } \\
\text { all } \\
(2)\end{array}$ & $\begin{array}{r}\text { Work } \\
\text { young } \\
(3)\end{array}$ & $\begin{array}{r}\text { Life } \\
\text { all } \\
(4)\end{array}$ & $\begin{array}{r}\text { Work } \\
\text { all } \\
(5)\end{array}$ & $\begin{array}{r}\text { Work } \\
\text { young } \\
(6)\end{array}$ \\
\hline $\begin{array}{l}y(t-1) \\
y(t-2)\end{array}$ & $\begin{array}{l}0.1459^{* * *} \\
(0.0230)\end{array}$ & $\begin{array}{c}0.2764^{* * *} \\
(0.0289) \\
0.0974^{* * *} \\
(0.0264)\end{array}$ & $\begin{array}{l}0.1640^{* * *} \\
(0.0438)\end{array}$ & $\begin{array}{l}0.1690^{* * *} \\
(0.0285)\end{array}$ & $\begin{array}{l}0.1530^{* * *} \\
(0.0267)\end{array}$ & $\begin{array}{l}0.1835^{* * *} \\
(0.0590)\end{array}$ \\
\hline$b m i$ & $\begin{array}{r}0.0072 \\
(0.0894)\end{array}$ & $\begin{array}{r}0.2976 \\
(0.1926)\end{array}$ & $\begin{array}{l}0.4859^{* * *} \\
(0.1843)\end{array}$ & $\begin{array}{l}0.2251^{* * *} \\
(0.0867)\end{array}$ & $\begin{array}{r}0.0592 \\
(0.1138)\end{array}$ & $\begin{array}{r}0.2319 \\
(0.2159)\end{array}$ \\
\hline$(b m i)^{2}$ & $\begin{array}{l}-0.0001 \\
(0.0015)\end{array}$ & $\begin{array}{l}-0.0047 \\
(0.0032)\end{array}$ & $\begin{array}{l}-0.0083^{* * *} \\
(0.0032)\end{array}$ & $\begin{array}{l}-0.0039^{* * *} \\
(0.0014)\end{array}$ & $\begin{array}{l}-0.0011 \\
(0.0019)\end{array}$ & $\begin{array}{l}-0.0041 \\
(0.0037)\end{array}$ \\
\hline $\ln ($ earnings $)$ & $\begin{array}{l}0.5288^{* * *} \\
(0.1104)\end{array}$ & $\begin{array}{l}0.7225^{* * *} \\
(0.1970)\end{array}$ & $\begin{array}{l}1.1844^{* * * *} \\
(0.2371)\end{array}$ & $\begin{array}{l}0.4188^{* * *} \\
(0.1324)\end{array}$ & $\begin{array}{l}1.1373^{* * *} \\
(0.1605)\end{array}$ & $\begin{array}{l}1.4494^{* * *} \\
(0.3347)\end{array}$ \\
\hline $\ln ($ hours $)$ & $\begin{array}{r}0.0080 \\
(0.1489)\end{array}$ & $\begin{array}{r}-0.1447 \\
(0.2711)\end{array}$ & $\begin{array}{c}-0.2224 \\
(0.3641)\end{array}$ & $\begin{array}{r}-0.0125 \\
(0.1640)\end{array}$ & $\begin{array}{r}0.2097 \\
(0.2177)\end{array}$ & $\begin{array}{r}0.0347 \\
(0.4033)\end{array}$ \\
\hline schooling & $\begin{array}{c}0.0228^{* *} \\
(0.0113)\end{array}$ & $\begin{array}{l}-0.0121 \\
(0.0192)\end{array}$ & $\begin{array}{l}-0.0395 \\
(0.0249)\end{array}$ & $\begin{array}{r}0.0188 \\
(0.0153)\end{array}$ & $\begin{array}{l}-0.0806^{* * *} \\
(0.0188)\end{array}$ & $\begin{array}{l}-0.1272^{* * *} \\
(0.0357)\end{array}$ \\
\hline age & $\begin{array}{l}-0.1161^{* * *} \\
(0.0147)\end{array}$ & $\begin{array}{l}-0.0939^{* * *} \\
(0.0229)\end{array}$ & $\begin{array}{l}-0.1108^{*} \\
(0.0567)\end{array}$ & $\begin{array}{l}-0.0840^{* * *} \\
(0.0171)\end{array}$ & $\begin{array}{l}-0.0729^{* * *} \\
(0.0215)\end{array}$ & $\begin{array}{l}-0.1396^{* *} \\
(0.0560)\end{array}$ \\
\hline$(\text { age })^{2}$ & $\begin{array}{l}0.0011^{* * *} \\
(0.0002)\end{array}$ & $\begin{array}{l}0.0008^{* * *} \\
(0.0002)\end{array}$ & $\begin{array}{r}0.0010 \\
(0.0008)\end{array}$ & $\begin{array}{l}0.0008^{* * *} \\
(0.0002)\end{array}$ & $\begin{array}{c}0.0007^{* * *} \\
(0.0002)\end{array}$ & $\begin{array}{l}0.0018^{* *} \\
(0.0007)\end{array}$ \\
\hline East Germany & $\begin{array}{l}-0.1698^{* * *} \\
(0.0619)\end{array}$ & $\begin{array}{r}0.0268 \\
(0.0925)\end{array}$ & $\begin{array}{r}0.0137 \\
(0.1111)\end{array}$ & $\begin{array}{l}-0.3478^{* * *} \\
(0.0588)\end{array}$ & $\begin{array}{c}-0.0808 \\
(0.0727)\end{array}$ & $\begin{array}{r}0.1282 \\
(0.1498)\end{array}$ \\
\hline married & $\begin{array}{l}0.1891^{* * *} \\
(0.0434)\end{array}$ & $\begin{array}{l}-0.1136^{*} \\
(0.0586)\end{array}$ & $\begin{array}{c}-0.1223 \\
(0.0843)\end{array}$ & $\begin{array}{l}0.2773^{\text {*** }} \\
(0.0561)\end{array}$ & $\begin{array}{l}0.4038^{* * *} \\
(0.0698)\end{array}$ & $\begin{array}{l}0.4744^{* * *} \\
(0.1222)\end{array}$ \\
\hline Observations & 11,514 & 6,611 & 2,906 & 8,910 & 8,910 & 2,506 \\
\hline Persons & 4,858 & 3,209 & 1,639 & 3,963 & 3,963 & 1,509 \\
\hline Arellano- & correlation & (p-value) & & & & \\
\hline first order & 0.0000 & 0.0000 & 0.0000 & 0.0000 & 0.0000 & 0.0000 \\
\hline second order & 0.1544 & $\mathrm{n} / \mathrm{a}$ & 0.6846 & 0.3969 & 0.6965 & 0.1257 \\
\hline Hansen test on instr & ument exoge & neity (p-value) & & & & \\
\hline Model & 0.2821 & 0.5347 & 0.2956 & 0.3583 & 0.6664 & 0.1604 \\
\hline$\Delta J$ for level eq. & 0.2576 & 0.0856 & 0.1179 & 0.5375 & 0.5596 & 0.4059 \\
\hline Instruments & 70 & 58 & 70 & 70 & 70 & 70 \\
\hline Implied $b m i^{o p t .}$ & 47.5 & 32.0 & 29.4 & 28.8 & 26.1 & 28.1 \\
\hline
\end{tabular}

Remarks: Method of estimation: System-GMM. Models additionally include an intercept term and year dummies. Robust standard errors with Windmeijer correction in parentheses. $* / * * / * * *$ indicates statistical significance at the $10 / 5 / 1 \%$ level. See text for definition of subsamples.

coefficient (on $y(t-1)$ ) is far below 1 , so the difference between the effect on impact and in the long run is modest. Nonetheless it turns out as highly significant and thus points to a mild form of persistence in subjective well-being.

\section{Conclusion}

That a single notch of bmi can make a difference of (up to) $3 \%$ in hourly wage in the long run is quite a large effect. This result stands in contrast to earlier literature that did not find a significant effect of bmi on wages in Germany (Cawley et al. 2005, Bozoyan and Wolbring, 2011). One reason may be be found in the more sluggish labour market in Germany (compared to the US) in the sense that 
there is earnings persistence. Our model accommodates for persistence, which is found to play a statistically significant - though economically only modest-role. In addition, our model allows bmi to exert a non-linear influence. To our knowledge, previous parametric approaches of modeling the non-linearity in this relationship considered $b m i$ to be an exogenous variable (Greve, 2008). The relatively high turning point (between overweight and obesity) is somewhat puzzling. Notice, though, that longevity also reaches its peak in the overweight category (Flegal et al., 2013). Our result could suggest that the movement from normal weight into the overweight category by a considerable share of the workforce does not jeopardize productivity.

Furthermore, our results underline the country-specific nature of the $b m i$-wage relationship (Brunello and D'Hombres, 2007). In contrast to results for the US, we find evidence for a significant effect of $b m i$ on earnings not only for female workers but also for young male workers Averett and Korenman, 1996, Cawley, 2004, Baum and Ford, 2004). For these young men we also document a remarkably similar relationship with work satisfaction when earnings are already controlled for. The mechanisms behind this relationship constitute an avenue for further research.

\section{References}

Andini, C., 2013a. Earnings persistence and schooling returns. Economics Letters $118,482-484$.

Andini, C., 2013b. How well does a dynamic Mincer equation fit NLSY data? Evidence based on a simple wage-bargaining model. Empirical Economics 44, 1519-1543.

Averett, S., Korenman, S., 1996. The economic reality of the beauty myth. Journal of Human Resources 31, 304-330.

Baum, C.L., Ford, W.F., 2004. The wage effects of obesity: a longitudinal study. Health Economics 13, 885-899.

Blundell, R., Bond, S., 1998. Initial conditions and moment restrictions in dynamic panel data models. Journal of Econometrics 87, 115-143.

Bozoyan, C., Wolbring, T., 2011. Fat, muscles, and wages. Economics and Human Biology 9, 356-363.

Brunello, G., D'Hombres, B., 2007. Does body weight affect wages?: Evidence from Europe. Economics \& Human Biology 5, 1-19. 
Cameron, C.A., Trivedi, P.K., 2005. Microeconometrics: methods and applications. Cambridge University Press.

Carr, D., Friedman, M.A., 2005. Is obesity stigmatizing? Body weight, perceived discrimination, and psychological well-being in the United States. Journal of Health and Social Behavior 46, 244-259.

Cawley, J., 2004. The Impact of Obesity on Wages. Journal of Human Resources 39, 451-474.

Cawley, J., Grabka, M.M., Lillard, D.R., 2005. A comparison of the relationship between obesity and earnings in the U.S. and Germany. Schmollers Jahrbuch: Journal of Applied Social Science Studies 125, 119-129.

Chen, A.J., 2012. When does weight matter most? Journal of Health Economics $31,285-295$.

Flegal, K.M., Kit, B.K., Orpana, H., Graubard, B.I., 2013. Association of all-cause mortality with overweight and obesity using standard body mass index categories. Journal of the American Medical Association 309, 71-82.

Franz, W., Pfeiffer, F., 2006. Reasons for wage rigidity in germany. Labour 20, 255-286.

Greve, J., 2008. Obesity and labor market outcomes in denmark. Economics \& Human Biology 6, 350-362.

Katsaiti, M.S., 2012. Obesity and happiness. Applied Economics 44, 4101-4114.

Kripfganz, S., Schwarz, C., 2013. Estimation of linear dynamic panel data models with time-invariant regressors. Unpulished manuscript, Goethe University Frankfurt.

Nickell, S., 1997. Unemployment and labor market rigidities: Europe versus north america. Journal of Economic Perspectives 11, 55-74.

Pinkston, J.C., 2010. The dynamic effects of obesity on the wages of young workers. Unpublished manuscript.

Puhl, R.M., Heuer, C.A., 2009. The stigma of obesity: A review and update. Obesity 17, 941-964.

Roodman, D.M., 2009a. How to do xtabond2: An introduction to difference and system gmm in stata. Stata Journal 9, 86-136.

Roodman, D.M., 2009b. Practitioners' corner. A note on the theme of too many instruments. Oxford Bulletin of Economics and Statistics 71, 135-158.

Socio-economic Panel (SOEP), 2012. Data for years 1984-2011. 10.5684/soep.v28.

Wagner, G.G., Frick, J.R., Schupp, J., 2007. The german socio-economic panel study (soep) - scope, evolution and enhancements. Schmollers Jahrbuch: Journal of Applied Social Science Studies 127, 139-169. 


\section{Appendix}

Table 4: Wage regression results, minimum number of instruments

\begin{tabular}{|c|c|c|c|c|}
\hline & \multicolumn{2}{|c|}{ Male workers } & \multicolumn{2}{|c|}{ Female workers } \\
\hline & $\begin{array}{l}\text { all } \\
(1)\end{array}$ & $\begin{array}{r}\text { young } \\
(2)\end{array}$ & $\begin{array}{l}\text { all } \\
(3)\end{array}$ & $\begin{array}{r}\text { young } \\
(4)\end{array}$ \\
\hline$y(t-1)$ & $\begin{array}{l}0.1954^{* * *} \\
(0.0389)\end{array}$ & $\begin{array}{l}0.2850^{* * *} \\
(0.0694)\end{array}$ & $\begin{array}{l}0.1512^{\text {*** }} \\
(0.0439)\end{array}$ & $\begin{array}{l}0.2420^{* * *} \\
(0.0706)\end{array}$ \\
\hline$b m i$ & $\begin{array}{r}0.0260 \\
(0.0283)\end{array}$ & $\begin{array}{c}0.1432^{*} \\
(0.0827)\end{array}$ & $\begin{array}{l}0.0534^{* *} \\
(0.0217)\end{array}$ & $\begin{array}{c}0.0906^{* *} \\
(0.0380)\end{array}$ \\
\hline$(b m i)^{2}$ & $\begin{array}{l}-0.0004 \\
(0.0005)\end{array}$ & $\begin{array}{l}-0.0025 \\
(0.0016)\end{array}$ & $\begin{array}{l}-0.0009 * * \\
(0.0004)\end{array}$ & $\begin{array}{l}-0.0017^{* * *} \\
(0.0006)\end{array}$ \\
\hline schooling & $\begin{array}{l}0.0677^{* * *} \\
(0.0036)\end{array}$ & $\begin{array}{l}0.0609^{* * *} \\
(0.0060)\end{array}$ & $\begin{array}{l}0.0759^{* * *} \\
(0.0044)\end{array}$ & $\begin{array}{l}0.0637^{* * *} \\
(0.0059)\end{array}$ \\
\hline East Germany & $\begin{array}{l}-0.3277^{* * *} \\
(0.0203)\end{array}$ & $\begin{array}{l}-0.2298^{* * *} \\
(0.0316)\end{array}$ & $\begin{array}{l}-0.2315^{* * *} \\
(0.0184)\end{array}$ & $\begin{array}{l}-0.2192^{* * *} \\
(0.0287)\end{array}$ \\
\hline $\begin{array}{l}\text { experience } \\
{\text { (experience })^{2}}^{2}\end{array}$ & $\begin{array}{l}0.0229^{* * *} \\
(0.0028) \\
-0.0004^{* * *} \\
(0.0001) \\
\end{array}$ & $\begin{array}{r}0.0078 \\
(0.0151) \\
0.0004 \\
(0.0006) \\
\end{array}$ & $\begin{array}{l}0.0208^{* * *} \\
(0.0031) \\
-0.0003^{* * *} \\
(0.0001) \\
\end{array}$ & $\begin{array}{r}0.0135 \\
(0.0136) \\
-0.0002 \\
(0.0006) \\
\end{array}$ \\
\hline Observations & 11,514 & 2,906 & 8,910 & 2,506 \\
\hline Persons & 4,858 & 1,639 & 3,963 & 1,509 \\
\hline \multicolumn{5}{|c|}{ Arellano-Bond autocorrelation test (p-value) } \\
\hline first order & 0.0000 & 0.0004 & 0.0000 & 0.0000 \\
\hline second order & 0.9973 & 0.3019 & 0.7595 & 0.7523 \\
\hline \multicolumn{5}{|c|}{ Hansen test on instrument exogeneity (p-value) } \\
\hline Model & 0.5715 & 0.8972 & 0.4129 & 0.6886 \\
\hline$\Delta J$ for level eq. & 0.2856 & 0.7711 & 0.3531 & 0.5975 \\
\hline Instruments & 28 & 28 & 28 & 28 \\
\hline Implied bmi $i^{\text {opt. }}$ & 33.3297 & 28.7162 & 30.1148 & 26.3209 \\
\hline
\end{tabular}

Remarks: Method of estimation: System-GMM. Models additionally include an intercept term and year dummies. Robust standard errors with Windmeijer correction in parentheses. $* / * * / * * *$ indicates statistical significance at the $10 / 5 / 1 \%$ level. See text for definition of subsamples. 
Table 5: Regression results for satisfaction with life and work, minimum number of instruments

\begin{tabular}{|c|c|c|c|c|c|c|}
\hline & \multicolumn{3}{|c|}{ Male workers } & \multicolumn{3}{|c|}{ Female workers } \\
\hline & $\begin{array}{r}\text { Life } \\
\text { all } \\
(1)\end{array}$ & $\begin{array}{r}\text { Work } \\
\text { all } \\
(2)\end{array}$ & $\begin{array}{r}\text { Work } \\
\text { young } \\
(3)\end{array}$ & $\begin{array}{r}\text { Life } \\
\text { all } \\
(4)\end{array}$ & $\begin{array}{r}\text { Work } \\
\text { all } \\
(5)\end{array}$ & $\begin{array}{r}\text { Work } \\
\text { young } \\
(6)\end{array}$ \\
\hline$y(t-1)$ & $\begin{array}{l}0.1264^{* * *} \\
(0.0236)\end{array}$ & $\begin{array}{l}0.2713^{* * *} \\
(0.0300)\end{array}$ & $\begin{array}{l}0.1590^{* * *} \\
(0.0475)\end{array}$ & $\begin{array}{l}0.1704^{* * *} \\
(0.0280)\end{array}$ & $\begin{array}{l}0.1561^{* * *} \\
(0.0283)\end{array}$ & $\begin{array}{l}0.1925^{* * *} \\
(0.0615)\end{array}$ \\
\hline$y(t-2)$ & & $\begin{array}{l}0.0921^{* * *} \\
(0.0273)\end{array}$ & & & & \\
\hline$b m i$ & $\begin{array}{r}0.0367 \\
(0.0922)\end{array}$ & $\begin{array}{r}0.2800 \\
(0.1769)\end{array}$ & $\begin{array}{l}0.4875^{* *} \\
(0.2097)\end{array}$ & $\begin{array}{c}0.2203^{* *} \\
(0.0919)\end{array}$ & $\begin{array}{r}0.0574 \\
(0.1234)\end{array}$ & $\begin{array}{r}0.0442 \\
(0.2290)\end{array}$ \\
\hline$(b m i)^{2}$ & $\begin{array}{l}-0.0006 \\
(0.0015)\end{array}$ & $\begin{array}{l}-0.0041 \\
(0.0029)\end{array}$ & $\begin{array}{l}-0.0082^{* *} \\
(0.0036)\end{array}$ & $\begin{array}{l}-0.0039^{* *} \\
(0.0015)\end{array}$ & $\begin{array}{l}-0.0011 \\
(0.0020)\end{array}$ & $\begin{array}{l}-0.0010 \\
(0.0039)\end{array}$ \\
\hline $\ln ($ earnings $)$ & $\begin{array}{l}0.4951^{* * *} \\
(0.1151)\end{array}$ & $\begin{array}{l}0.7568^{* * *} \\
(0.2073)\end{array}$ & $\begin{array}{l}1.2065^{* * *} \\
(0.2575)\end{array}$ & $\begin{array}{l}0.4152^{\text {*** }} \\
(0.1375)\end{array}$ & $\begin{array}{l}1.1606^{* * *} \\
(0.1643)\end{array}$ & $\begin{array}{l}1.4900^{* * *} \\
(0.3363)\end{array}$ \\
\hline $\ln ($ hours $)$ & $\begin{array}{r}0.0529 \\
(0.1545)\end{array}$ & $\begin{array}{l}-0.2518 \\
(0.2890)\end{array}$ & $\begin{array}{l}-0.3393 \\
(0.3541)\end{array}$ & $\begin{array}{r}0.0068 \\
(0.1653)\end{array}$ & $\begin{array}{r}0.3672 \\
(0.2265)\end{array}$ & $\begin{array}{r}0.1049 \\
(0.4109)\end{array}$ \\
\hline schooling & $\begin{array}{l}0.0270^{* *} \\
(0.0117)\end{array}$ & $\begin{array}{l}-0.0107 \\
(0.0204)\end{array}$ & $\begin{array}{l}-0.0405 \\
(0.0262)\end{array}$ & $\begin{array}{r}0.0179 \\
(0.0159)\end{array}$ & $\begin{array}{l}-0.0865^{* * *} \\
(0.0191)\end{array}$ & $\begin{array}{l}-0.1357^{* * *} \\
(0.0355)\end{array}$ \\
\hline age & $\begin{array}{l}-0.1156^{* * *} \\
(0.0149)\end{array}$ & $\begin{array}{l}-0.0992^{* * *} \\
(0.0237)\end{array}$ & $\begin{array}{l}-0.1038^{*} \\
(0.0580)\end{array}$ & $\begin{array}{l}-0.0778^{* * *} \\
(0.0175)\end{array}$ & $\begin{array}{l}-0.0686^{* * *} \\
(0.0217)\end{array}$ & $\begin{array}{l}-0.1470^{* *} \\
(0.0571)\end{array}$ \\
\hline$(a g e)^{2}$ & $\begin{array}{l}0.0011^{* * *} \\
(0.0002)\end{array}$ & $\begin{array}{l}0.0009^{* * *} \\
(0.0002)\end{array}$ & $\begin{array}{r}0.0009 \\
(0.0008)\end{array}$ & $\begin{array}{l}0.0008^{* * *} \\
(0.0002)\end{array}$ & $\begin{array}{l}0.0006^{* *} \\
(0.0002)\end{array}$ & $\begin{array}{l}0.0020^{* * *} \\
(0.0008)\end{array}$ \\
\hline East Germany & $\begin{array}{l}-0.2018^{* * *} \\
(0.0642)\end{array}$ & $\begin{array}{r}0.0426 \\
(0.0963)\end{array}$ & $\begin{array}{r}0.0120 \\
(0.1140)\end{array}$ & $\begin{array}{l}-0.3544^{* * *} \\
(0.0597)\end{array}$ & $\begin{array}{l}-0.1025 \\
(0.0739)\end{array}$ & $\begin{array}{r}0.1512 \\
(0.1465)\end{array}$ \\
\hline married & $\begin{array}{l}0.1914^{* * * *} \\
(0.0439)\end{array}$ & $\begin{array}{l}-0.1274^{* *} \\
(0.0600)\end{array}$ & $\begin{array}{l}-0.1452 \\
(0.0892)\end{array}$ & $\begin{array}{l}0.2632^{* * *} \\
(0.0572)\end{array}$ & $\begin{array}{l}0.4330^{* * *} \\
(0.0710)\end{array}$ & $\begin{array}{l}0.5065^{* * *} \\
(0.1224)\end{array}$ \\
\hline Observations & 11,514 & 6,611 & 2,906 & 8,910 & 8,910 & 2,506 \\
\hline Persons & 4,858 & 3,209 & 1,639 & 3,963 & 3,963 & 1,509 \\
\hline Arellano-Bond autoc & correlation te & st (p-value) & & & & \\
\hline first order & 0.0000 & 0.0000 & 0.0000 & 0.0000 & 0.0000 & 0.0000 \\
\hline second order & 0.2146 & $\mathrm{n} / \mathrm{a}$ & 0.6741 & 0.3941 & 0.7021 & 0.1334 \\
\hline Hansen test on instr & ument exoge & heity (p-value) & & & & \\
\hline Model & 0.3083 & 0.1633 & 0.0307 & 0.2345 & 0.6749 & 0.6280 \\
\hline$\Delta J$ for level eq. & 0.5829 & 0.1651 & 0.0591 & 0.4828 & 0.7083 & 0.5615 \\
\hline Instruments & 43 & 37 & 43 & 43 & 43 & 43 \\
\hline Implied $b m i^{o p t .}$ & 31.1166 & 34.1286 & 29.6071 & 28.4887 & 26.5217 & 21.4691 \\
\hline
\end{tabular}

Remarks: Method of estimation: System-GMM. Models additionally include an intercept term and year dummies. Robust standard errors with Windmeijer correction in parentheses. ${ }^{*} / * * / * * *$ indicates statistical significance at the $10 / 5 / 1 \%$ level. See text for definition of subsamples. 
Table 6: Wage regression results, bmi linear

\begin{tabular}{|c|c|c|c|c|}
\hline & \multicolumn{2}{|c|}{ Male workers } & \multicolumn{2}{|c|}{ Female workers } \\
\hline & $\begin{array}{l}\text { all } \\
(1)\end{array}$ & $\begin{array}{r}\text { young } \\
(2)\end{array}$ & $\begin{array}{l}\text { all } \\
(3)\end{array}$ & $\begin{array}{r}\text { young } \\
(4)\end{array}$ \\
\hline$y(t-1)$ & $\begin{array}{l}0.1904^{* * *} \\
(0.0384)\end{array}$ & $\begin{array}{c}0.1536^{* *} \\
(0.0671)\end{array}$ & $\begin{array}{l}0.1610^{* * *} \\
(0.0416)\end{array}$ & $\begin{array}{c}0.2675^{* * *} \\
(0.0641)\end{array}$ \\
\hline$b m i$ & $\begin{array}{r}0.0020 \\
(0.0032)\end{array}$ & $\begin{array}{r}0.0016 \\
(0.0069)\end{array}$ & $\begin{array}{r}0.0040 \\
(0.0031)\end{array}$ & $\begin{array}{l}-0.0028 \\
(0.0053)\end{array}$ \\
\hline schooling & $\begin{array}{l}0.0679^{* * *} \\
(0.0036)\end{array}$ & $\begin{array}{l}0.0707^{* * *} \\
(0.0060)\end{array}$ & $\begin{array}{l}0.0747^{* * * *} \\
(0.0042)\end{array}$ & $\begin{array}{l}0.0608^{* * * *} \\
(0.0053)\end{array}$ \\
\hline East Germany & $\begin{array}{l}-0.3316^{* * *} \\
(0.0202)\end{array}$ & $\begin{array}{l}-0.2708^{* * *} \\
(0.0306)\end{array}$ & $\begin{array}{l}-0.2278^{* * *} \\
(0.0178)\end{array}$ & $\begin{array}{l}-0.2104^{* * *} \\
(0.0275)\end{array}$ \\
\hline experience & $\begin{array}{l}0.0237^{* * *} \\
(0.0027)\end{array}$ & $\begin{array}{c}0.0303^{* *} \\
(0.0152)\end{array}$ & $\begin{array}{l}0.0214^{* * *} \\
(0.0030)\end{array}$ & $\begin{array}{r}0.0128 \\
(0.0128)\end{array}$ \\
\hline$(\text { experience })^{2}$ & $\begin{array}{l}-0.0004^{* * *} \\
(0.0001)\end{array}$ & $\begin{array}{c}-0.0004 \\
(0.0007)\end{array}$ & $\begin{array}{l}-0.0003^{* * *} \\
(0.0001)\end{array}$ & $\begin{array}{r}-0.0001 \\
(0.0006)\end{array}$ \\
\hline Observations & 11,514 & 2,906 & 8,910 & 2,506 \\
\hline Persons & 4,858 & 1,639 & 3,963 & 1,509 \\
\hline \multicolumn{5}{|c|}{ Arellano-Bond autocorrelation test (p-value) } \\
\hline first order & 0.0000 & 0.0018 & 0.0000 & 0.0000 \\
\hline second order & 0.9636 & 0.0693 & 0.8219 & 0.8201 \\
\hline \multicolumn{5}{|c|}{ Hansen test on instrument exogeneity (p-value) } \\
\hline Model & 0.8666 & 0.1020 & 0.4997 & 0.8795 \\
\hline$\Delta J$ for level eq. & 0.8844 & 0.4043 & 0.3302 & 0.4695 \\
\hline Instruments & 24 & 30 & 30 & 30 \\
\hline
\end{tabular}

Remarks: Method of estimation: System-GMM. Models additionally include an intercept term and year dummies. Robust standard errors with Windmeijer correction in parentheses. $* / * * / * * *$ indicates statistical significance at the $10 / 5 / 1 \%$ level. See text for definition of subsamples. 